\title{
Pengungkapan Islamic Socal Reporting, ROA, ROE Dan BOPO : Pada Bank Syariah Di Indonesia Tahun 2015-2017
}

\author{
Dyah Ayu Perwitasari \\ Universitas Panca Marga Probolinggo \\ dyahayu@upm.ac.id
}

\begin{abstract}
Abstrak
Pengungkapan CSR dengan menggunakan indeks Global Initiative Reporting (GRI) terbatas pada aspek material. Pengukuran GRI berbeda dengan pengukuran pengungkapan CSR dengan menggunakan indikator Islamic Social Reporting (ISR) yang menggunakan aspek spiritual dan sosial. Tujuan penelitian ini untuk mengetahui apakah Islamic Social Responsibility disclosure memberikan pengaruh terhadap ROA (Return On Investment), ROE (Return on Equity) dan BOPO pada perbankan syariah di Indonesia tahun 2015-2017. Sampel dalam Penelitian kuantitatif ini adalah 10 BUS di Indonesia. Variabel Independent pada penelitian ini menggunakan indikator Islamic Social Reporting disclosure (ISR), sedangkan variabel dependentnya adalah ROA, ROE, dan BOPO. Hasil dari uji pada penelitian ini adalah Islamic Social reporting mempunyai pengaruh positif dan signifikan terhadap ROA dan ROE. Sedangkan pengungkapan ISR tidak berpengaruh terhadap BOPO.
\end{abstract}

\section{Kata kunci: CSR, Islamic Social Reporting, ROA, ROE, BOPO}

\begin{abstract}
Disclosure of CSR using the Global Initiative Reporting (GRI) index is limited to material aspects. The GRI measurement is different from measuring CSR disclosure by using the Islamic Social Reporting (ISR) indicator that uses spiritual and social aspects. The purpose of this study is to determine whether Islamic Social Responsibility disclosure has an influence on ROA (Return on Investment), ROE (Return on Equity) and BOPO in Islamic banking in Indonesia in 2015-2017. The sample in this quantitative study is 10 BUSs in Indonesia. The Independent variable in this study uses the Islamic Social Reporting disclosure (ISR) indicator, while the dependent variables are ROA, ROE, and BOPO. The results of the test in this study are Islamic Social reporting has a positive and significant effect on ROA and ROE. While ISR disclosure does not affect BOPO.
\end{abstract}

\section{Keyword: CSR, Islamic Social Reporting, ROA, ROE, BOPO}

\section{PENDAHULUAN}

Pada era globalisasi perekonomian dunia berkembang dengan pesat. Keterlibatan dan kerjasama dibidang ekonomi antar berbagai Negara di dunia merupakan bukti dari pengaruh perekonomian global. Pada era pasar bebas perusahaan baik skala nasional maupun multinasional harus mempersiapkan diri dalam menghadapi tantangan yang semakin kompetitif. Sektor perbankan syariah merupakan entitas yang berkembang di Indonesia. Perbankan syariah menjalankan usahanya berdasarkan prinsip-prinsip syariah yakni bentuk pelarangan riba yang telah ditentukan oleh DSN. Data yang termuat pada laporan OJK bulan Oktober 2018, badan usaha syariah (BUS) berjumlah 13 BUS dan 20 Unit Usaha Syariah (UUS).

Tumbuhnya lembaga keuangan di sektor syariah, merupakan bukti bahwa masyarakat di Indonesia memberikan respon positif terhadap hadirnya bank-bank yang menerapkan prinsip syariah. Kinerja yang positif di sektor keuangan syariah tersebut, tentunya harus diimbangi dengan kegiatan sosial sebagai bentuk pertanggungjawaban perusahaan bagi masyarakat dan lingkungan. CSR merupakan kegiatan yang dilakukan entitas bisnis dalam wujud kepedulian kepada masyrakat dan lingungan yang diatur pemeritah yang tertuang dalam Undang-undang. Menurut Fauziah dan Yudho (2013) menyatakan bahwa keberlangsungan perusahaan ditentukan jika perusahaan memperhatikan keempat aspek yakni keuntungan, pembangungan manusia, lingkungan, dan prosedur (profit, people planet dan procedure).

Bank konvensional maupun bank syariah memuat secara rutin tentang laporan kegiatan CSR. Pelaporan pertanggung jawaban sosial pada entitas bisnis di sektor syariah menggunakan item standar ISR yang telah ditetapkan oleh AAOFI. Hanifa (2002) mengungkapan tentang adanya keterbatasan pada item standar pada pelaporan konvensional CSR sehingga diperlukan adanya kerangka konseptual untuk membuat laporan yang mengacu pada aspek syariah. Pengungkapan ISR memiliki tujuan yaitu sebagai bentuk pertanggungajawaban (akuntabilitas) kepada Allah SWT dan relevansi informasi yang transparan atas operasional perusahaan kepada stakeholder.

Konsep pengungkapan ISR melibatkan beberapa elemen antara lain masyarakat, pemerintah dan perusahaan. Apabila perusahaan menerapkan praktik CSR sesuai dengan prinsip-prinsip syariah, 
diharapkan dapat memberikan citra baik dan meningkatkan kinerja perusahaan. Hasil penelitian Arifin dan Wardana (2016) membuktikan bahwa reputasi dan ROE dipengaruhi oleh pengungkapan ICSR, sedangkan ROA tidak dipengaruhi oleh tingkat pengungkapan ICSR. Hal tersebut senada dengan Arshad et.al (2012) membuktikan jika perusahaan melakukan pengungkapan CSR, maka dapat meningkatkan kinerja keuangannya. Penelitian Husnan (2013) juga menunjukkan bahw ROA tidak dipengaruhi oleh luas pengungkapan CSR, sedangkan ROS (Return on Sales) tidak berpengaruh terhadap ROE dan current ratio.

Kegiatan CSR dapat menyebabkan biaya operasional perusahaan menjadi menurun. Hal ini disebabkan perusahaan akan menekan biaya pemasaran produk dengan menggantinya pada biaya kegiatan CSR. Kegiatan CSR merupakan kegiatan perusahaan sebagai bentuk kepedulian terhadap masyarakat, konsumen, dan lingkungan. Kegiatan CSR yang berkelanjutan dapat memberikan manfaat jangka panjang pada perusahaan, walaupun disisi lain perusahaan juga akan mengeluarkan biaya operasional yang cukup tinggi pula.

Kegiatan CSR perusahaan yang diterapkan dengan baik, tentunya juga melakukan laporan pengungkapan CSR dengan baik pula. Perusahaan yang mengungkapkan dengan baik laporan CSRnya, memberikan sinyal yang baik bagi shareholder maupun stakeholder. Bukti dari respon positif dari stakeholder adalah meningkatnya loyalitas, kepercayaan, dan produk dapat diterima dengan baik sehingga meningkatkan kinerja keuangan. Oleh karena itu, pengungkapan CSR dapat memberikan hubungan positif dengan keuntungan atau laba perusahaan..

Berdasarkan latar belakang di atas, peneliti akan melakukan pengujian pengaruh pengungkapan Islamic Social Reporting terhadap ROA, ROE, dan BOPO pada bank umum syariah tahun 2015-2017. Tujuan penelitian ini untuk membuktikan pengaruh dari pengungkapan Islamic Social Reporting terhadap ROA, ROE dan BOPO pada bank umum syariah tahun 2015-2017.

\section{KAJIAN PUSTAKA \\ Corporate Social Responsibility (CSR)}

Corporate social responsibility merupakan komitmen perusahaan untuk meningkatkan kesejahteraan komunitas melalui praktik bisnis yang baik dan mengkonstribusikan sebagian sumber daya perusahaan (Kotler\&Nancy, 2005). Sedangkan menurut Accounting and Auditing Organization for Islamic Financial Institutions (AAOFI) CSR menurut perpesktif Islam adalah kegiatan yang dilakukan oleh institusi financial Islam untuk memenuhi kepentingan religius, ekonomi, hukum, etika dan discretionary responsibilities sebagai lembaga financial intermediary baik individu maupun institusi. Dengan demikian, CSR dalam konteks ekonomi Islam kegiatan bisnis perusahaan yang mempunyai tanggung jawab etis menurut prinsipprinsip syariah.

\section{Islamic Social Responsility (ISR)}

Perusahaan yang berbasis syariah, menggunakan indeks social reporting (ISR) dalam melakukan pelaporan tanggungjawab sosial perusahaan. Bentuk laporan kinerja sosial perusahaan dilaporkan melalui laporan tahunan perusahaan. Namun, untuk mengetahui penerapan ISR bagi entitas syariah, pedoman yang digunakan adalah indeks ISR yang dikeluarkan oleh AAOFI dan dikembangkan oleh peneliti lainnya dimana tidak hanya mencakup aspek material namun spiritual.

\section{Kinerja keuangan Bank}

Kinerja keuangan digunakan untuk mengukur dan menilai kondisi keuangan sebuah perusahaan. Rentabilitas atau earning ROA, ROE, dan BOPO. ROA menujukkan kemampuan perusahaan dalam pengelolaan aktiva perusahaan untuk menghasilkan laba. Kemampuan dalam pengelolaan modal perusahaan dapat diukur dengan rasio ROE. Sedangkan besaran efesiensi operasional perusahaan dengan menggunakan indikator BOPO.

\section{Hipotesis}

Profitabilitas menurut Harahap (2004) disebut juga dengan rentabilitas. Berdasarkan teori stakeholder, perusahaan cenderung memberikan periotas atas tuntutan yang dibuat oleh pihak-pihak yang memiliki kepentingan (stakeholder) yakni pihak lingkungan luar organisasi. Dengan demikian, jika perusahaan memenuhi tuntutan dari stakeholder, dapat meningkatkan pendapatan perusahaan.

Penelitian yang mendukung adalah penelitian Husnan (2013) dimana profitabilitas yang diukur dengan rasio ROA DAN ROS dipengaruhi oleh tingkat pengungkapan CSR, sedangkan CSR disclosure tidak ada pengaruh signifikan terhadap ROE dan ROS. Sedangkan penelitian Wirakusuma dkk (2009) CSR sebagai variabel moderasi memiliki pengaruh positif terhadap ROA dan nilai perusahaan. Penelitian Shahnaz (2013) juga memberikan bukti bahwa ROA dan ROE dipengaruhi oleh penerapan CSR. Pada penelitian ini profitabilitas atau rentabilitas diukur dengan menggunakan ROA, ROE, dan BOPO. Penelitian ini menggunakan hipotesis sebagai berikut:

H1: Islamic Social Responsibility Disclosure mempunyai pengaruh positif dan signifikan terhadap ROA. H2: Islamic Social Responsibility Disclosure mempunyai pengaruh positif dan signifikan terhadap ROE. H3: Islamic Social Responsibility Disclosure mempunyai pengaruh positif dan signifikan terhadap BOPO. 


\section{METODOLOGI PENELITIAN}

Laporan tahunan yang diterbitkan melalui laman perusahaan pada tahun 2015-2017 merupakan data sekunder yang digunakan oleh peneliti dengan 10 sampel perusahaan bank umum syariah. Purposive sampling digunakan untuk teknik dalam pengambilan sampel pada penelitian kuantitatif ini yaitu bank umum syariah yang telah melakukan penerbitan laporan tahunan melalui laman perusahaan tahun 2015-2017.

Tingkat pengungkapan ISR yang dimuat pada laporan tahunan digunakan sebagai variabel independent dalam penelitian ini. ISR indeks yang digunakan adalah dari penelitian Oman dan Thani (2009) dengan jumlah 48 item yang dihitung dalam satuan persentase. Content analysis digunakan oleh peneliti dengan mengidentifikasi item-item ISR yang dimuat pada laporan tahunan dan memberikan nilai/skor 0 jika tidak memuat pengungkapan pada laporan tahunan dan nilai 1 jika diungkapkan dalam laporan tahunan. Sedangkan ROA, ROE dan BOPO digunakan sebagai variabel dependent. Setelah dilakukan penskoran terhadap item-item pada laporan tahunan ISR dianalisis dengan menggunakan SPPS versi 21.0 dengan menggunakan regresi dalam menguji hipotesis sehingga dapat ditarik kesimpulan hubungan antara variabel.

\section{HASIL DAN PEMBAHASAN \\ Pengujian Analisis Diskriptif}

Tabel 1

\begin{tabular}{|l|r|r|r|r|r|}
\hline & $\mathrm{N}$ & Minimum & Maximum & \multicolumn{1}{c|}{ Mean } & Std. Deviation \\
\hline ISRD & 30 & .67 & .92 & .7777 & .08144 \\
ROE & 30 & -94.01 & 11.97 & -4.1620 & 23.34823 \\
ROA & 30 & -10.77 & 2.63 & -.3607 & 2.91002 \\
BOPO & 30 & 86.88 & 217.40 & 102.5253 & 25.03924 \\
Valid N (listwise) & 30 & & & & \\
\hline
\end{tabular}

Pada tabel 1 menunjukkan bahwa variabel independen (ISRD) dan variabel dependent (ROA, ROE, BOPO) pada bank syariah Indonesia yang ditunjukkan dengan mean sebesar $77 \%$ (cukup baik). Nilai minimal dari hasil pengujian sebesar $67 \%$, sedangkan nilai maksimalnya adalah sebesar $92 \%$.

\section{Hasil Pengujian Koefisien Determinasi}

Pengujian koefisien determinasi dari tiga variabel yakni:

Tabel 2

\begin{tabular}{|l|r|r|r|r|}
\hline Model & $\mathrm{R}$ & $\mathrm{R}$ Square & $\begin{array}{c}\text { Adjusted R } \\
\text { Square }\end{array}$ & $\begin{array}{c}\text { Std. Error of } \\
\text { the Estimate }\end{array}$ \\
\hline 1 & $.378^{\mathrm{a}}$ & .143 & .113 & 2.74124 \\
\hline
\end{tabular}

Tabel 3

\begin{tabular}{|l|r|r|r|r|}
\hline Model & $\mathrm{R}$ & $\mathrm{R}$ Square & $\begin{array}{c}\text { Adjusted R } \\
\text { Square }\end{array}$ & $\begin{array}{c}\text { Std. Error of } \\
\text { the Estimate }\end{array}$ \\
\hline 1 & $.394^{\mathrm{a}}$ & .155 & .125 & 21.84051 \\
\hline
\end{tabular}

Tabel 4

\begin{tabular}{|l|r|r|r|r|}
\hline Model & \multicolumn{1}{|c|}{$\mathrm{R}$} & $\mathrm{R}$ Square & $\begin{array}{c}\text { Adjusted R } \\
\text { Square }\end{array}$ & $\begin{array}{c}\text { Std. Error of } \\
\text { the Estimate }\end{array}$ \\
\hline 1 & $.288^{\mathrm{a}}$ & .083 & .050 & 24.40443 \\
\hline
\end{tabular}

Pada tabel 2, tabel 3 dan tabel 4 menghasilkan nilai adjusted square sebesar $29 \%$. Variabel ROA menghasilkan nilai adjusted square sebesar $11 \%$, Variabel ROE menghasilkan nilai adjusted Square sebesar 0,13 atau $13 \%$, sedangkan variabel BOPO menghasilkan $5 \%$. Sehingga total nilai adjusted square sebesar $29 \%$. Angka tersesebut sebagai bukti bahwa 29\% pengungkapan ISR pada bank syariah tahun 2015-2017 dapat berpengaruh terhadap kinerja keuangan. Sedangkan 71\% tidak diteliti pada penelitian ini.

\section{Hasil pengujian hipotesis}

Hasil pengujian hipotesis pada penelitian ini antara lain:

1. Islamic Social Responsibility Disclosure mempunyai pengaruh positif dan signifikan terhadap ROA

Pengujian regresi pada hipotesis pertama sebagai berikut:

Tabel 5

\begin{tabular}{|rl|r|r|r|r|r|}
\hline \multicolumn{2}{|l|}{ Model } & \multicolumn{2}{|c|}{ Unstandardized Coefficients } & $\begin{array}{c}\text { Standardized } \\
\text { Coefficients }\end{array}$ & \multirow{2}{*}{ S } & \multirow{2}{*}{} \\
\cline { 3 - 5 } & \multicolumn{1}{|c|}{$\mathrm{B}$} & \multicolumn{1}{|c|}{ Std. Error } & \multicolumn{1}{c|}{ Beta } & & \\
\hline \multirow{2}{*}{1} & (Constant) & -10.877 & 4.887 & & -2.226 & .034 \\
& ISRD & 13.523 & 6.251 & .378 & 2.164 & .039 \\
\hline
\end{tabular}


a. Dependent Variable: ROA

Pada tabel 5. diketahui bahwa nilai siginifikansi $0.04 \quad(0.04<0.05)$. ROA diperngaruhi oleh ISRD. Penelitian yang mendukung adalah penelitian yang dilakukan oleh Husnan (2013) bahwa ROA dipengaruhi oleh tingkat CSR disclosure. Penerapan CSR yang konsisten dapat memberikan keuntungan bagi perusahaan, yakni sebagai bahan pertimbangan bagi calon investor. Perusahaan yang menghasilkan keuntungan yang tinggi, berpeluang akan melaporkan kinerja perusahaan secara luas sehingga dapat memberikan nilai positif bagi perusahaan.

2. Islamic Social Responsibility Disclosure mempunyai pengaruh positif dan signifikan terhadap ROE

Pengujian regresi pada hipotesis ke dua sebagai berikut:

Tabel 6

\begin{tabular}{|c|c|c|c|c|c|}
\hline \multirow[t]{2}{*}{ Model } & \multicolumn{2}{|c|}{ Unstandardized Coefficients } & Standardized & \multirow[t]{2}{*}{$\mathrm{T}$} & \multirow[t]{2}{*}{ Sig. } \\
\hline & $B$ & Std. Error & Beta & & \\
\hline $\begin{array}{l}\text { (Constant) } \\
\text { ISRD }\end{array}$ & $\begin{array}{l}-91.983 \\
112.928\end{array}$ & $\begin{array}{l}38.933 \\
49.800\end{array}$ & .394 & $\begin{array}{r}-2.363 \\
2.268\end{array}$ & $\begin{array}{l}.025 \\
.031\end{array}$ \\
\hline
\end{tabular}

a. Dependent Variable: ROE

Pada tabel 6. diketahui bahwa nilai siginifikansi sebesar $0.03 \quad(0.03<0.05)$. Kesimpulannya adalah bahwa ISR disclosure berpengaruh positif dan signfikan terhadap ROE. Penelitian yang mendukung adalah penelitian Wardani dan Arifin (2016) bahwa ISR disclosure berpengaruh positif dan signfikan terhadap ROE. Perusahaan yang memperoleh profit yang tinggi, maka akan memberikan kompensasi yang baik pula bagi stakeholder sehingga akan memberikan citra dan reputasi yang baik pula bagi perusahaan.

3. Islamic Social Responsibility Disclosure mempunyai pengaruh positif dan signifikan terhadap BOPO

Pengujian regresi pada hipotesis ke tiga sebagai berikut:

Tabel 7

\begin{tabular}{|rl|r|r|r|r|r|}
\hline \multicolumn{2}{|l|}{ Model } & \multicolumn{2}{|l|}{ Unstandardized Coefficients } & $\begin{array}{c}\text { Standardized } \\
\text { Coefficients }\end{array}$ & \multirow{2}{*}{ T } & \multirow{2}{*}{ Sig. } \\
\cline { 3 - 4 } & \multicolumn{1}{|c|}{$\mathrm{B}$} & \multicolumn{1}{|c|}{ Std. Error } & \multicolumn{1}{c|}{ Beta } & & \\
\hline \multirow{2}{*}{1} & (Constant) & 171.335 & 43.503 & & 3.938 & .000 \\
& ISRD & -88.482 & 55.646 & -.288 & -1.590 & .123 \\
\hline
\end{tabular}

a. Dependent Variable: BOPO

Tabel 7 menunjukkan bahwa signifikansi sebesar $0.12(0.12>0.05)$. Hasil uji t membuktikan bahwa Islamic social responsibility disclosure tidak mempunyai pengaruh pada BOPO. Hasil penelitian ini berbeda dari Permanasari (2012) bahwa CSR berpengaruh positif terhadap BOPO. Perbedaan hasil ini penelitian tersebut salah satunya dikarenakan bank syariah menggunakan dana kebajikan, zakat, maupun laba yang berasal yang berasal nasabah maupun karyawan untuk disalurkan dalam kegiatan CSR tersebut. Dengan demikian, pihak bank tidak menggunakan dana operasional perusaahan yang dapat menambah beban operasional perusahaan.

\section{KESIMPULAN DAN SARAN \\ Kesimpulan}

Kesimpulan dari analisis diatas adalah sebagai berikut:

1. Pengungkapan ISR positif dan signifikan mempengaruhi ROA. Semakin luas pengungkapan Islamic Social Reporting, maka dapat meningkatkan profitabilitas perusahaan yang diukur oleh ROA.

2. Pengungkapan ISR positif dan signifikan mempengaruhi ROE. Semakin luas pengungkapan Islamic Social Reporting, maka dapat meningkatkan tingkat profitabilitas.

3. Pengungkapan ISR negative tidak mempengaruhi BOPO. Dengan demikian luas pengungkapan ISR,

\section{Saran} tidak berpengaruh terhadap beban operasional terhadap pendapatan operasioanal.

1. Periode penelitian yang digunakan hanya menggunakan 3 periode yaitu pada tahun 2015-2017 sehingga peneliti selanjutnya diharapkan dapat menambah periode penelitiannya.

2. Penilaian indeks ISR dengan menggunakan content analysis menyebabkan unsur subjektivitas. Sehingga pada penelitian selanjutnya, dapat menggunakan metode survey yang dinilai lebih objektif.

3. Perlunya menambah variabel dependent dan independent dalam penelitian selanjutnya yaitu apakah dengan pengungkapan dengan menggunakan ISR secara luas, dapat berpengaruh terhadap performance financial dengan RGEC.

\section{DAFTAR PUSTAKA}


Arshad, R. S. Othman dan R. Othman. 2012. Islamic Corporate Social Responsibility, Corporate Reputation and Perfomance. International Journal of Social, Behavioral, Educational, Economic, Business and Industrial Enginering 6(4): 643-647

Fauziah, K.,\& Yudho, P. 2013. Analisis Pengungkapan Tanggung Jawab Social Perbanka Syariah di Indonesia berdasarkan Islamic Social Reporting Indeks. Jurnal Dinamika Akuntansi, 5 No.1.

Hasan, A., dan S.S Harahap. 2010. Exploring Corporate Social Responsibility Disclosure: The Case of Islamic Banks. International Journal Of Islamic and Middle Eastern Finance and Management 3(3): 203227.

Husnan, Ahmad. 2013. Pengaruh Coporate Social Responsibility (CSR Disclosure) Terhadap Kinerja Keuangan Perusahaan. Skripsi. Semarang: Universitas Diponegoro.

Kotler, Philip dan Nancy. 2005. Manajemn Pemasaran. Jilid 1 dan 2. Jakarta: PT. Indeks Kelompok Gramedia.

Othaman, R, Thani. 2009. Determinants Of Islamic Social Reporting Among Top Sharia- Approved Companies In Bursa Malaysia. Research Journal Of International Studies.

Permanasari, Mirra. 2012. Pengaruh Penerapan Corporate Social Responsibility Terhadap Tingkat Profitabilitas, Besaran Pajak Penghasilan dan Biaya Operasi Pada Perusahaan Yang Terdaftar di Bursa Efek Indonesia.

Syahnaz, M. 2013. Pengaruh Corporate Social Responsibility terhadap Kinerja Keuangan Perusahan Perbankan. Jurnal Ilmiah Mahasiswa FEB Universitas Brawijaya Vol 1, No.2, Tahun 2013.

Wardani, Arifin. 2016. Islamic Corporate Social Responsibility Disclosure, Reputasi, dan Kinerja Keuangan: Studi Bank Syariah di Indonesia. Jurnal Akuntansi dan Auditing Indonesia 20 (1), 38-46.

Yuniasih, N.W., dan M.G. Wirakusuma. 2009. Pengaruh Kinerja Keuangan terhadap Nilai Perusahaan dengan Pengungkapan Corporate Responsibility dan Good Governance Sebagai Variabel Pemoderasi. Jurnal Ilmiah Akuntansi dan Bisnis 4(1): 1-10. 